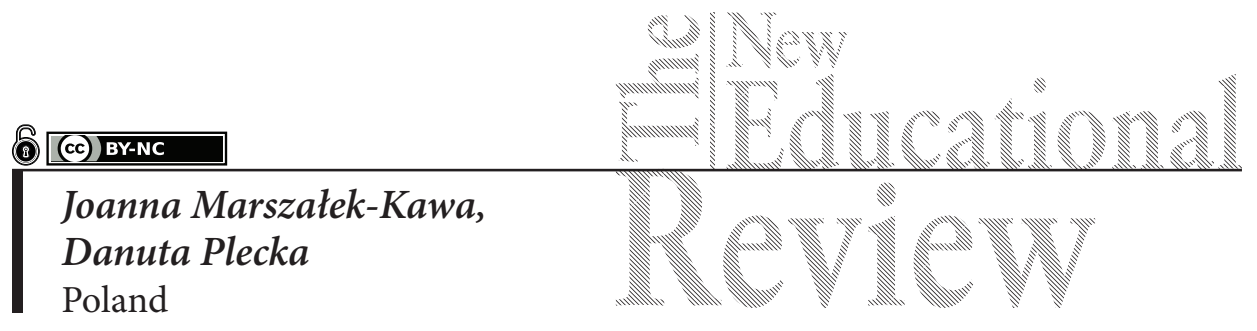

\title{
Education and Political Subjectivity. A Study Report
}

DOI: 10.15804/tner.2019.57.3.01

\begin{abstract}
It is obvious that the educational system shapes the skill of critical thinking, also in the sphere of the assessment of political phenomena. The educational background of a person determines the kind of decisions he or she makes. These decisions refer to political activity both defined as interest in political issues and manifested in the form of active political participation. The aim of this paper is to identify relations between holding a university degree and political subjectivity. The study, conducted with the use of a survey questionnaire, involved students from the University of Zielona Góra and from the Nicolaus Copernicus University in Toruń.
\end{abstract}

Keywords: education, political subjectivity, democracy

Among different concepts of democracy, it is those, which stress citizens' involvement as the prerequisite for the development and proper functioning of a regime that are of prime importance (Diamond, 2002, p. 213; Thomassen, 2007, pp. 418-434; Dahl 1957, pp. 201-215; Dahl 1998, pp. 217; Sartori, 1998, pp. 58-298; Morison, 2007, pp. 134-156). There may be different types of citizens' political activity: engagement, and passive and active participation. The broadest notion concerning political activity is an individual's interest in politics which takes different forms (e.g. attitudes to political values, manifesting one's political views, etc.). Participation refers to people's activities undertaken for the sake of 
changing or continuing policy, thus determining their attitude towards it (Kruikemeier, van Noort, Vliegenthart, de Vreese, 2014, pp. 903-920; Sotwin, 2003, pp. 12-23; Turska-Kawa, 2011, pp. 267-280; Wolfson, n.d.). Political participation and involvement may assume different forms (symbolic vs. real, or idealistic vs. realistic), but they are based on the same factor, referred to as political subjectivity.

The category of subjectivity was borrowed from social psychology. As Wiesława Sotwin points out, subjectivity can be of an external or internal nature, with both kinds mutually excluding each other. They "represent two basic aspects of subjectivity, i.e. the possibility of being the driving force for the external environment and for oneself" (Sotwin, 2003, p. 14-16). Both phenomena are a reflection of the state of mind. Subjectivity should be viewed on a few levels and with reference to various situations. According to Milton Rokeach, personality is determined by a system of values (Rokeach, 1973, pp. 14-16), which do not have to be mutually contradictory as they are based on logic. Their primary task is to influence the psychological sphere of an individual. Rokeach claims that one of the fundamental dimensions of the analysis of beliefs is the criterion of openness-closedness. Their bases include sources of information, its relevance and irrelevance, and an individual's ability to select it. As Sotwin points out "the more closed the mind is, the more difficult it is for it to distinguish between information and its origin, and to evaluate them separately. A sense of danger and fear are the main reasons for which the mind closes" (Sotwin, 2003, p. 48-53). This determines authoritarian attitudes consisting in a belief that one has to subject to authorities, who constitute quite an idealized picture. It is also connected with the conviction that one cannot make decisions concerning his or her life and has no influence, whatsoever, on the surrounding reality. Therefore, the subjectivity of an individual becomes shaken as a consequence of the external influence of the society as a whole, or its particular groups (for example, a family). What is the opposite of an authoritarian attitude is people's conviction that they can both decide on their faith and have an impact on the surrounding reality. Thus, subjectivity emerges, following the comparison of intentions with the accomplished targets.

This also concerns political subjectivity. Krzysztof Korzeniowski listed four models of political subjectivity. The first of them occurs in the dimension of effectiveness vs. helplessness, i.e. individuals' belief that they are able to influence the reality vs. the conviction that they cannot do it. The second dimension refers to sense/nonsense, i.e. the belief that our actions are meaningful or are pointless. The third sphere concerns a sense of enomy vs. anomy, i.e. the assumption that people have/do not have the capability to assess the reality. The final domain involves a sense of identification vs. alienation, i.e. a sense of belonging to and integration 
with the system vs. a sense of alienation and lack of identification with the system (Korzeniowski, 1993, pp. 155-192).

The subjectivity of an individual is undoubtedly affected by one's upbringing, but also by education at all levels - starting from nursery school to the university. The educational system allows people to develop the skill of critical thinking. This also concerns the political phenomena. As a result, an individual's decisions concerning the sphere of political activity are confined to taking an interest in politics or to political participation. One of the primary tasks of the educational process is to take care of the comprehensive growth of an individual, taking into consideration the necessity of developing personal talents. This poses a number of challenges for the system of schools and higher education, which may result in the fulfilment of some very important social functions (Brennan, 2008, pp. 381-393; Luvalo, 2014, pp. 1206-1212; Cortese, 2003, pp. 15-22). The requirements for the individual stages of education assume that each of them should support an individual in the increasingly comprehensive growth of personality and a sense of subjectivity. It contributes not only to the development of an individual, but also of human capital, which is necessary in the process of economic growth and for the stabilization of democracy as a political regime. In turn, education which does not favour the development of subjectivity, including the political one, is conducive to the intensification of populist and authoritarian attitudes.

\section{The research problem and methodology}

The aim of the study presented below is to identify relations between higher education and political subjectivity. A survey questionnaire is the best choice in the case of examining such specific phenomena as relations between one's education and his or her sense of agency. It makes it possible to present a large catalogue of questions concerning the issue.

The study was conducted between October 2018 and March 2019. Its participants included students of the Nicolaus Copernicus University in Torun and the University of Zielona Góra. There were a total of 129 respondents: 47 people from the University of Zielona Góra and 82 from the Nicolaus Copernicus University. The main research problem concerned the relationship between one's level of education and a sense of political subjectivity. 


\section{Research findings}

The group of questions regarding education included those about the reason for studying (three answers could be ticked). The respondents most frequently stressed their willingness to become a highly qualified specialist, the need to raise their social status and to ensure permanent income. Leading an interesting life as a result of obtaining a university degree was also a popular answer.

Table 1. Why did you decide to study.

Based on the authors' own research

\begin{tabular}{|c|c|c|c|c|c|}
\hline & $\mathbf{N}$ & $\begin{array}{l}\text { Mini- } \\
\text { mum }\end{array}$ & $\begin{array}{l}\text { Maxi- } \\
\text { mum }\end{array}$ & Mean & $\begin{array}{l}\text { Standard } \\
\text { deviation }\end{array}$ \\
\hline $\begin{array}{l}\text { I wanted to become a highly qualified spe- } \\
\text { cialist in the chosen field. }\end{array}$ & 129 & 0 & 1 & .27 & .446 \\
\hline $\begin{array}{l}\text { I wanted to raise my social status, have } \\
\text { a more prestigious position in the society. }\end{array}$ & 129 & 0 & 1 & .34 & .476 \\
\hline $\begin{array}{l}\text { I wanted to secure myself a steady income } \\
\text { in future. }\end{array}$ & 129 & 0 & 1 & .36 & .483 \\
\hline $\begin{array}{l}\text { I wanted to prolong my school years (with- } \\
\text { out having to work, with no obligations, etc.). }\end{array}$ & 129 & 0 & 1 & .13 & .340 \\
\hline $\begin{array}{l}\text { I believed that a university diploma (regard- } \\
\text { less of the kind of studies) would be useful } \\
\text { in life. }\end{array}$ & 129 & 0 & 1 & .31 & .464 \\
\hline I wanted to meet my life partner here. & 129 & 0 & 1 & .04 & .194 \\
\hline My parents insisted I take up studies. & 129 & 0 & 1 & .08 & .268 \\
\hline $\begin{array}{l}\text { I thought that a university degree would } \\
\text { allow me to lead an interesting life now and } \\
\text { in future. }\end{array}$ & 129 & 0 & 1 & .38 & .487 \\
\hline $\begin{array}{l}\text { I believed that owing to studies I would } \\
\text { become a well-educated and well-mannered } \\
\text { person. }\end{array}$ & 129 & 0 & 1 & .19 & .397 \\
\hline $\begin{array}{l}\text { I wanted to continue a family tradition and } \\
\text { follow in my parents' (or one of the parents') } \\
\text { footsteps regarding the choice of profession. }\end{array}$ & 129 & 0 & 1 & .02 & .151 \\
\hline I wanted to live and study in a big city. & 129 & 0 & 1 & .12 & .331 \\
\hline $\begin{array}{l}\text { I decided to study because almost everyone } \\
\text { does so nowadays. }\end{array}$ & 129 & 0 & 1 & .09 & .292 \\
\hline $\begin{array}{l}\text { I wanted to experience students' life, have } \\
\text { fun and entertain myself. }\end{array}$ & 129 & 0 & 1 & .17 & .378 \\
\hline It is difficult to say. & 129 & 0 & 1 & .03 & .174 \\
\hline Valid N (excluding with observations) & 129 & & & & \\
\hline
\end{tabular}


From the perspective of our study, it was important to ask students about the reasons for choosing the field of study. The most frequent answer was that after graduation, they could work in a socially useful profession (sociology and internal security).

Table 2. Why did you choose this field of study?

Based on the authors' own research

\begin{tabular}{|c|c|c|c|c|c|}
\hline & $\mathrm{N}$ & $\begin{array}{l}\text { Mini- } \\
\text { mum }\end{array}$ & $\begin{array}{l}\text { Maxi- } \\
\text { mum }\end{array}$ & Mean & $\begin{array}{l}\text { Standard } \\
\text { deviation }\end{array}$ \\
\hline I am interested in this field of knowledge. & 129 & 0 & 1 & .60 & .492 \\
\hline $\begin{array}{l}\text { I was not admitted to my dreamed field of } \\
\text { study. }\end{array}$ & 129 & 0 & 1 & .06 & .242 \\
\hline It was easy to get in this field of study. & 129 & 0 & 1 & .15 & .356 \\
\hline $\begin{array}{l}\text { There are good job prospects after complet- } \\
\text { ing these studies. }\end{array}$ & 129 & 0 & 1 & .29 & .454 \\
\hline My parents persuaded me. & 129 & 0 & 1 & .03 & .174 \\
\hline $\begin{array}{l}\text { My friends/colleagues chose this field of } \\
\text { study. }\end{array}$ & 129 & 0 & 1 & .06 & .242 \\
\hline It is a prestigious field of study. & 129 & 0 & 1 & .09 & .292 \\
\hline $\begin{array}{l}\text { This is an easy subject, there is not a lot to } \\
\text { learn, not much effort is needed. }\end{array}$ & 129 & 0 & 1 & .16 & .363 \\
\hline It is a family tradition. & 129 & 0 & 1 & .02 & .124 \\
\hline $\begin{array}{l}\text { After completing my studies, I will be able to } \\
\text { work in a socially useful job. }\end{array}$ & 129 & 0 & 1 & .47 & .501 \\
\hline $\begin{array}{l}\text { Owing to obtaining a degree in this field of } \\
\text { study, I will be able to travel all around the } \\
\text { world. }\end{array}$ & 129 & 0 & 1 & .12 & .331 \\
\hline Valid N (excluding with observations) & 129 & & & & \\
\hline
\end{tabular}

The respondents indicated self-development and the possibility of acting for the good of other people as the most important benefits of doing their chosen job in the future. 
Table 3. What benefits resulting from doing your future job are especially important for you? Based on the authors' own research

\begin{tabular}{lccccc}
\hline & $\mathrm{N}$ & $\begin{array}{c}\text { Mini- } \\
\text { mum }\end{array}$ & $\begin{array}{c}\text { Maxi- } \\
\text { mum }\end{array}$ & Mean & $\begin{array}{c}\text { Standard } \\
\text { deviation }\end{array}$ \\
\hline $\begin{array}{l}\text { The possibility of making use of and } \\
\text { developing one's talents, the possibility of } \\
\text { self-fulfilment }\end{array}$ & 129 & 0 & 1 & .39 & .489 \\
\hline $\begin{array}{l}\text { The possibility of acting for the good of } \\
\text { other people, doing a socially useful job }\end{array}$ & 129 & 0 & 1 & .44 & .499 \\
\hline The possibility of performing a creative job & 129 & 0 & 1 & .11 & .312 \\
\hline Respect from other people & 129 & 0 & 1 & .27 & .446 \\
\hline High social prestige & 129 & 0 & 1 & .17 & .378 \\
\hline Well-paid job & 129 & 0 & 1 & .29 & .454 \\
\hline $\begin{array}{l}\text { The possibility of having a high position in } \\
\text { the society }\end{array}$ & 129 & 0 & 1 & .10 & .302 \\
\hline $\begin{array}{l}\text { The possibility of cooperating with other } \\
\text { people }\end{array}$ & 129 & 0 & 1 & .40 & .492 \\
\hline A lot of free time & 129 & 0 & 1 & .03 & .174 \\
\hline $\begin{array}{l}\text { The possibility of solving problems autono- } \\
\text { mously }\end{array}$ & 129 & 0 & 1 & .09 & .292 \\
\hline Lack of physical effort & 129 & 0 & 1 & .05 & .227 \\
\hline The possibility of finding a job abroad & 129 & 0 & 1 & .12 & .331 \\
\hline No health risks involved & 129 & 0 & 1 & .02 & .151 \\
\hline $\begin{array}{l}\text { Flexible working time } \\
\text { The possibility of acquiring new knowledge } \\
\text { and skills }\end{array}$ & 129 & 0 & 129 & .43 & .496 \\
\hline The possibility of early retirement & 129 & 0 & 1 & .29 & .454 \\
\hline \begin{tabular}{l} 
Valid N (excluding with observations) \\
\hline
\end{tabular} & & & & & \\
\hline
\end{tabular}

What is interesting, social sensitivity, which the respondents indicated as one of the reasons behind choosing their future position, is not a hint when it comes to the choice of ideological orientations. The majority of students under survey identified themselves with national-democratic $(27.9 \%)$ or liberal $(22.5 \%)$ views. As our other studies show, the respondents' answers reflect the lack of political knowledge rather than their actual political beliefs (Marszałek-Kawa, Plecka, 2018, pp. 20-29). The following research findings confirm this statement. 
Table 4. Which of the ideological orientations below is the closest to you? Based on the authors' own research

\begin{tabular}{|c|c|c|c|c|c|}
\hline & & $\begin{array}{l}\text { Empiri- } \\
\text { cal prob- } \\
\text { ability }\end{array}$ & $\begin{array}{l}\text { Percent- } \\
\text { age }\end{array}$ & $\begin{array}{l}\text { Valid } \\
\text { percent- } \\
\text { age }\end{array}$ & $\begin{array}{l}\text { Cumula- } \\
\text { tive per- } \\
\text { centage }\end{array}$ \\
\hline \multirow[t]{13}{*}{ Valid } & Communist & 2 & 1.6 & 1.7 & 1.7 \\
\hline & Socialist & 2 & 1.6 & 1.7 & 3.3 \\
\hline & Social-democratic & 4 & 3.1 & 3.3 & 6.6 \\
\hline & Liberal & 29 & 22.5 & 24.0 & 30.6 \\
\hline & National-democratic & 36 & 27.9 & 29.8 & 60.3 \\
\hline & Ecological & 4 & 3.1 & 3.3 & 63.6 \\
\hline & Christian-democratic & 14 & 10.9 & 11.6 & 75.2 \\
\hline & $\begin{array}{l}\text { None of the above because each of } \\
\text { them has flaws. }\end{array}$ & 4 & 3.1 & 3.3 & 78.5 \\
\hline & $\begin{array}{l}\text { It is difficult to say because I do } \\
\text { not know what they differ in. }\end{array}$ & 21 & 16.3 & 17.4 & 95.9 \\
\hline & Centrism & 1 & .8 & .8 & 96.7 \\
\hline & Democratic & 2 & 1.6 & 1.7 & 98.3 \\
\hline & Islamic & 2 & 1.6 & 1.7 & 100.0 \\
\hline & Total & 121 & 93.8 & 100.0 & \\
\hline $\begin{array}{l}\text { Missing } \\
\text { data }\end{array}$ & 99 & 8 & 6.2 & & \\
\hline Total & & 129 & 100.0 & & \\
\hline
\end{tabular}

Against the background of political beliefs, the issue of political activity, as a reflection of political subjectivity, looks quite interesting. While it was to some degree possible to state that the respondents were able to identify their ideological preferences, these are not manifested in the public sphere whatsoever. The majority do not support any forms of protest regardless of their character (55\% of the people under survey). If any form of a demonstration of political views appears, it is confined to signing endorsement lists referring to specific actions. 
Table 5. In what way do you demonstrate your attitude?

Based on the authors' own research

\begin{tabular}{|c|c|c|c|c|c|}
\hline & & $\begin{array}{l}\text { Empirical } \\
\text { probability }\end{array}$ & Percentage & $\begin{array}{l}\text { Valid per- } \\
\text { centage }\end{array}$ & $\begin{array}{l}\text { Cumulative } \\
\text { percentage }\end{array}$ \\
\hline \multirow[t]{6}{*}{ Valid } & $\begin{array}{l}\text { I take part in: demonstra- } \\
\text { tions, picket lines. }\end{array}$ & 11 & 8.5 & 8.6 & 8.6 \\
\hline & I sign endorsement lists. & 31 & 24.0 & 24.2 & 32.8 \\
\hline & I take part in happenings. & 8 & 6.2 & 6.3 & 39.1 \\
\hline & $\begin{array}{l}\text { I do not support any } \\
\text { forms of protest. }\end{array}$ & 71 & 55.0 & 55.5 & 94.5 \\
\hline & 9 & 7 & 5.4 & 5.5 & 100.0 \\
\hline & Total & 128 & 99.2 & 100.0 & \\
\hline $\begin{array}{l}\text { Missing } \\
\text { data }\end{array}$ & 99 & 1 & .8 & & \\
\hline \multirow[t]{4}{*}{ Total } & & 129 & 100.0 & & \\
\hline & $\begin{array}{l}\text { National Radical Camp, } \\
\text { All-Polish Youth }\end{array}$ & 2 & 1.6 & 1.6 & 44.5 \\
\hline & $\begin{array}{l}\text { I identify myself with no } \\
\text { political party or social } \\
\text { movement. }\end{array}$ & 71 & 55.0 & 55.5 & 100.0 \\
\hline & Total & 128 & 99.2 & 100.0 & \\
\hline $\begin{array}{l}\text { Missing } \\
\text { data }\end{array}$ & 99 & 1 & .8 & & \\
\hline Total & & 129 & 100.0 & & \\
\hline
\end{tabular}

Another form of expressing political subjectivity is electoral participation. More than a half of our respondents $(53.5 \%)$ cast a vote in the last presidential election (2015). This clearly shows that students under survey consider electoral participation a lot more important than any other form of participation in the public sphere. However, we cannot state that this formula best reflects a sense of political subjectivity without further in-depth research in the field. 
Table 6. Did you vote in the last presidential election?

Based on the authors' own research

\begin{tabular}{llcccc}
\hline & & $\begin{array}{c}\text { Empirical } \\
\text { probability }\end{array}$ & Percentage & Valid percentage & $\begin{array}{c}\text { Cumulative } \\
\text { percentage }\end{array}$ \\
\hline \multirow{2}{*}{ Valid } & 0 & 18 & 14.0 & 14.1 & 14.1 \\
\cline { 2 - 6 } & Yes & 69 & 53.5 & 53.9 & 68.0 \\
\cline { 2 - 6 } & No & 41 & 31.8 & 32.0 & 100.0 \\
\cline { 2 - 6 } & Total & 128 & 99.2 & 100.0 & \\
\hline Missing data & 9 & 1 & .8 & & \\
\hline Total & \multicolumn{7}{c}{129} & 100.0 & & \\
\hline
\end{tabular}

\section{Conclusion}

The results of our study show that university education is of value to students thanks to the opportunities it opens in future - both in the individual and social dimension. Higher education shapes civil and social subjectivity - this is a conclusion from the most frequently chosen answers in the questionnaire. Educational background, however, does not significantly affect political subjectivity as manifested by participation or expressing one's political views. If we narrow down participation to electoral activity, we can observe acertain relationship between the phenomenon of education and political subjectivity - there is a growing awareness of participation, which is a sense of agency, i.e. the conviction than one can influence the surrounding reality.

\section{References}

Brennan, J. (2008). Higher education and social change. Higher Education, 56, 381-393.

Cortese, A.D. (2003). The Critical Role of Higher Education in Creating a Sustainable Future. Planning for Higher Education, 31(3), 15-22.

Dahl, R.A. (1957). The Concept of Power. Systems Research and Behavioral Science, 2(3), 201-215.

Dahl, R.A. (1998). On Democracy. New Haven-London: Yale University Press.

Diamond, L. (2002). Consolidating Democracies. In: L. LeDuc, R. Niemis, \& P. Norris (eds.), Comparing Democracies. New Challenges in the Study and Voting. London: SAGE Publications Ltd.

Korzeniowski, K. (1993). Alienacja polityczna a uczestnictwo polityczne w warunkach transformacji systemu [Political Alienation and Political Participation in the Conditions 
of the System Transformation]. In: J. Reykowski (ed.), Wartości i postawy społeczne a przemiany systemowe. Szkice z psychologii politycznej [Social Values and Attitudes and System Changes. Sketches in Political Psychology] (pp. 155-192). Warszawa: Wydawnictwo Instytut Psychologii PAN.

Kruikemeier, S., Noort, G. van, Vliegenthart, R. \& Vreese, C.H. de (2014). Unraveling the effects of active and passive forms of political Internet use: Does it affect citizens' political involvement? New Media \& Society, 16(6), 903-920.

Luvalo L.M. (2014). The Role of Higher Education in Social Transformation and Rural Development. Mediterranean Journal of Social Sciences, 5(23), 1206-1212.

Marszałek-Kawa, J., Plecka, D. (2018). Political Knowledge as the Basis for Building Mutual Relations in the International Arena. The Case of Poland and Azerbaijan. European Journal of Transformation Studies, 6(1), 20-29.

Morison, J. (2007). Models of Democracy: From Representation to Participation? In: J. Jowell, \& D. Oliver (Eds.), The Changing Constitution, 6 ${ }^{\text {th }}$ Edition (pp. 134-156). Oxford University Press.

Rokeach, M. (1973). The Nature of Human Values. New York: Free Press.

Sartori, G. (1962). Democratic Theory. Detroit: Wayne University Press.

Sotwin, W. (2003). Podmiotowość w sferze politycznej, czyli pragmatyzm-pryncypial$i z m$ [Subjectivity in the Political Sphere or Pragmatism-Principlism]. Warszawa: Wydawnictwo Naukowe "Scholar".

Thomassen, J.J.A. (2007). Democratic values. In: R.J. Dalton, H.-D. Klingemann (eds.), Oxford Handbook of Political Behavior (pp. 418-434). New York: Oxford University Press.

Turska-Kawa, A. (2011). Political Activation of Young People. On the Importance of the Humanities for Social Practice. In: B. Bokus (ed.). The Humanities Today and the Idea of Interdisciplinary Studies (pp. 267-280). Warsaw: Matrix.

Wolfson, M. (n.d.). Active vs. Passive voice: What's the difference? What should I use? And why does it matter? Retrieved from: https://www.aje.com/arc/writing-with-active-orpassive-voice/. 